\title{
Asynchronies and disturbances as a tool in analysing well-being problems at work
}

Kirsti Launis and Juha Pihlaja

\section{(2) OpenEdition}

1 Journals

\section{Electronic version}

URL: http://journals.openedition.org/activites/1718

DOI: $10.4000 /$ activites. 1718

ISSN: $1765-2723$

\section{Publisher}

ARPACT - Association Recherches et Pratiques sur les ACTivités

Electronic reference

Kirsti Launis and Juha Pihlaja, « Asynchronies and disturbances as a tool in analysing well-being problems at work », Activités [Online], 4-2 I octobre 2007, Online since 15 October 2007, connection on 19 April 2019. URL : http://journals.openedition.org/activites/1718; DOI : 10.4000/activites. 1718

\section{(c) $\oplus \Theta \Theta$}

Activités est mis à disposition selon les termes de la licence Creative Commons Attribution - Pas d'Utilisation Commerciale - Pas de Modification 4.0 International. 


\title{
Asynchronies and disturbances as a tool in analysing well-being problems at work
}

\author{
Kirsti Launis \\ Finnish institute of Occupational Health, Helsinki, Finland \\ Juha Pihlaja \\ Merikoski Rehabilitation and Research Center, Helsinki, Finland
}

\begin{abstract}
Recurrent changes at workplaces seem to increase the haste, stress, health complaints and safety problems of workers. OHS-professionals try to reduce stress or cure separate environmental problems and risk factors at work. However, in spite of their good intentions, in rapid change situations, these professionals may add to the confusion with their prevailing methods and recommendations. The dynamics of workplace transformations are not well understoodfrom theperspective of theeverydayworkofeithertheorganization or the individual. In this paper, the Activity Theoretical Approach is used to reconceptualize work-related well-being in situations of rapid change. Key concepts are production and service concepts and their asynchronies. Many asynchronies were observed in the analysis of the two cases of different types of organizations. These asynchronies caused frustration, confusion and lowered the work motivation and perceived well-being of employees. The nature of the load was called disturbance load. Our data and results show that rapid changes in production and service concepts are a major challenge for research on well-being, especially since continuous change has become an inseparable part of work life over the past ten years.
\end{abstract}

KEYWORDS

Activity Theory, production concept, work-related well-being, asynchrony

\section{1.- Introduction}

Numerous surveys have shown that perceived stress and health symptoms have increased, particularly since the beginning of the 1990s. A comprehensive survey (Kompier, Cooper, \& Geurts, 2000) showed that $25 \%$ of European workers perceived stress as the cause of health problems and lower work performance, even though they simultaneously reported that their working conditions had improved, and that occupational health services and training had increased (European Agency for Safety and Health at Work, 2002; De Greef, \& Van den Broek, 2004).

Doherty, Forslin, Shani and Kira (2002) argue that since the beginning of the 1990s, work intensity has grown because management is increasingly driven by short-term goals of competitiveness. There seem to be some aspects in work life which are causing more and more problems for personnel, but is management solely to blame for this?

Organizations hire specialists in occupational health, safety and ergonomics, and personnel development. In spite of their good intentions, these professionals may add to the confusion in rapid change situations with their prevailing concepts of occupational health and safety, working models and practical tools. 
When trying to reduce individual stress or risk factors at work, or cure separate environmental problems using traditional models, they may be merely helping to maintain the problems brought on by rapid change situations. We maintain that a part of the most common problem in work-related wellbeing stems from the theories, models and tools of the experts. For example, the most prominent theory base in occupational health service is epidemiology. Epidemiological theory and the practical tools based on the theory are not enough to understand the well-being problems caused by the transition process in workplaces.

In order to survive competition, organizations are constantly striving for more functional and costefficient production and service concepts. Although much has been written about this continuous change, it is not easy to identify the context and dynamics of such events, and they are not well understood from the perspective of either the organization or individual. In situations where the prevailing production or service concept does not correspond to business demands, or when new concepts are launched, several different disturbances occur in the organization (Engeström, 1988; Mäkitalo, 2005).

The transition process is not as smooth and linear as the management, experts and consultants usually claim. The work units and individual workers often experience the changes as challenging, but also as exhausting. The fluency of everyday work process is hindered by disruptions, disturbances, haste, or problems that are usually individualized as shortcomings of some personnel group (aged workers, newcomers, managers, planners), and attempts are made to overcome this by training or the creation of new regulations.

In our cases we started to analyze the transition process itself, as opposed to the characteristics of individual workers or separate stress factors of the work.

\section{2.- Research question, methods and data}

In the 2-year intervention project (2002-2004) based on the Cultural Historical Activity Theory (Engeström, Lompscher, \& Ruckriem, 2005) (CHAT) and the Change Laboratory method (Virkkunen, Engeström, Helle, Pihlaja, \& Poikela, 1997), we investigated the change processes of several Finnish work organizations. CHAT mediated our research questions for this paper.

The data for the two case analyses presented in this paper are based on the Change Laboratory interventions although we do not depict the intervention processes in this paper.

\section{1.-Research questions}

Although especially psycho-social well-being problems at work are based on individual experiences, instead of focusing on individuals, we focused on the transitions in the work process. Our assumption was that work-related well-being was closely related to the successful accomplishment of work, and well-being problems arise in situations where the fluency of the work process is disturbed. Furthermore, in the transition processes these disturbance situations, "noise in the flow of work" (Engeström, 1988) increase notably.

Data of the disturbance situations were gathered during the interventions, and our questions for this paper were:

1. What kind of change processes are going on in the organization?

2. What kind of disturbances can be found related to the ongoing change?

3. What is the relation between change and work-related well-being?

In our paper, we show that well-being is connected not only to quantitative changes in work load, but also to qualitative and historical changes in production. 


\section{2.-Cultural Historical Activity Theory}

Instead of choosing individual workers or patterns of detached environmental or stress factors, we chose local change situations as the unit of our analysis, and analyzed them in the context of the changing activity system of organizations. The historically developed and continuously changing activity system (Engeström, 1987; 2000) outlined, but did not restrict our analysis and interpretations.

We conceptualized the changes in activity systems as the qualitative and historical changes in production concepts and used the historically changing work types described by Victor and Boynton (1998). These work types represent different principles according to which production (or service) is organized. In order to put these changes into practice, companies have to learn new ways of organizing work, new processes, new types of knowledge, new kinds of manager-worker relations, and new kinds of information systems.

For the theoretical analysis of the changes in production and service concepts, we developed a description model (Launis, \& Pihlaja, 2005; Pihlaja, 2005). In the historical matrix we described four production and service concepts in detail: 1) craft production 2) mass production 3) flexible mass production, and 4) customized mass production.

\section{3.-Our data}

Our data come from two different organizations: from a paper mill, which is a traditional industrial organization, and from a municipal enterprise, which provides cleaning and catering services and real estate maintenance. We chose these two case examples because the former represents a private and industrial organization, and the latter, a public, municipal service organization. We used case data in our analysis as an example rather than as a comparison of the organizations.

In our interventions, our main interest was to promote the transition processes in organizations and some local work units in particular, in cooperation with the personnel. Together with them and the occupational health experts, we analyzed the change processes in the organizations. As data in our analysis, we used various material gathered in, during and after the intervention process from the pilot work units and the organization.

Data consisted of 1) descriptions of disturbances, disruptions, and situations perceived as disagreeable by the personnel in work units, 2) documents of the strategies, visions and plans of the organizations, 3) personnel and management interviews, 4) documents concerning solutions and decisions in organizational change situations, 5) audio-taped material and assignments of development processes during the intervention phase, and 6) own observations in the organizations.

\section{3.- Results and discussion}

Our results showed that the concepts had changed rapidly in organizations under study after the late 1990s. Up to the beginning of the 1990s, mass production or a corresponding service concept was dominant, but at the end of the decade, new concepts were launched ever more rapidly.

The development of new production concepts was essential in order to survive in the competitive market. When change processes were focused at grass root level disturbances, many asynchronies and collapses were observed both vertically and horizontally in organizations.

\section{1.- The increasing change cycle}

In industrial organization, a new concept seemed to be replacing the old one rapidly (Table 1). After a hundred years mass production, in 1993 the organization fell into a deep crisis because exports to the Soviet Union (a third of its whole capacity) were cut off "overnight". There were shutdowns, 
warnings of temporary dismissals, and the atmosphere was said to be oppressive.

\begin{tabular}{|c|c|c|c|}
\hline Années & $\begin{array}{c}\text { Standard. mass } \\
\text { production }\end{array}$ & $\begin{array}{c}\text { Flexible mass } \\
\text { prod.uction }\end{array}$ & $\begin{array}{c}\text { Custom. mass } \\
\text { production }\end{array}$ \\
\hline$\ldots$ & & & \\
\cline { 2 - 4 } 1991 & & & \\
\hline 1992 & & & \\
1995 & & & \\
\hline 1996 & & & \\
\hline 1999 & & & \\
\hline 2000 & & & \\
\hline$\ldots$ & & & \\
\hline
\end{tabular}

Table 1: Changes of production concepts in industrial organization during the last ten years.

In order to survive competition, the quality of the products, reliability, and cost-effectiveness had to be substantially improved. In collaboration with the personnel - using participative and team models - the management developed a novel production concept - flexible mass production. In 1995 a new quality system was constructed and new IT-solutions were introduced. At the end of the 1990s, strategic choices were made to select strategic clients to achieve custom-oriented production.

The results in Table 1 are based on the interview material and reports given (in the interventions). According to interview data, the change process seemed to proceed fluently, but descriptions of every day disturbances changed the picture.

\section{2.- Present disturbances reveal stratified concepts}

When we asked the paper mill workers to describe the concrete situations that they perceived as exhausting, nearly all descriptions were related to the new recently implemented data based production management system.

After the development project, we analyzed: 1) What type of production concept this kind of data system would underpin, 2) What kind of training system was in use when the data system was launched, 3) What kinds of solutions the workers proposed in their disturbance descriptions, 4) What kinds of solutions were developed when the training was insufficient, 5) What kinds of solutions the workers developed across traditional organizational boundaries. The results are summarized in Table 2.

The data system was constructed to support the production management system of the whole corporation in developing customization of the production (1) (numbers refer to Table 2).

The arranged training in implementing the new data system was based on the mass production concept in which every worker is trained according to the prevailing division of labor, for his/her own duties (2).

In implementation, workers faced many problems, and to solve the problems, they proposed that the division of labor and individual responsibilities should be precise and documented clearly - according to the previous mass production concept (3).

During the intervention the personnel set up work groups in the work units to construct forums to discuss regularly, analyze and solve problems as they came up (continuous improvement) (4).

Later it was also found that efficient and proper use of the system required regular meetings across department boundaries, to look for solutions to the problems, and to develop and use the system according to clients (5). 


\begin{tabular}{|c|c|c|c|}
\cline { 2 - 4 } \multicolumn{1}{c|}{} & $\begin{array}{c}\text { Standard. mass } \\
\text { production }\end{array}$ & $\begin{array}{c}\text { Flexible mass } \\
\text { production }\end{array}$ & $\begin{array}{c}\text { Custom. mass } \\
\text { production }\end{array}$ \\
\hline $\begin{array}{c}\text { (1) Production } \\
\text { management } \\
\text { system }\end{array}$ & & & \\
\hline $\begin{array}{c}\text { (2) Training } \\
\text { system }\end{array}$ & & & \\
\hline $\begin{array}{c}\text { (3) Proposed } \\
\text { solutions }\end{array}$ & & & \\
\hline $\begin{array}{c}\text { (4) Developed } \\
\text { solutions }\end{array}$ & & & \\
\hline (5) Developed \\
solutions
\end{tabular}

Table 2: Asynchronies in transition in an industrial organization.

Before the intervention, the problems were mainly interpreted as shortcomings in the competencies and skills of employees. We called the situations where different functions or departments tried to implement different production concepts asynchronies. The depicted horizontal asynchronies were partly overcome by the solutions where boundaries between different departments on the grass root level were crossed, and new demands of the clients were analyzed together.

\section{3.-Shifting between concepts- exhausting and frustrating}

In 2002, one goal of the management of the municipal service organization was to develop selfmanagerial teamwork in local service teams. The idea was that workers representing three different occupations could help each other, on their own initiative, across standardized professional boundaries. We interpreted this goal as an attempt to proceed from the mass production concept to flexible services (1), (numbers refer to Table 3).

The workers in a pilot team, nevertheless, were not interested in this teamwork model. On the contrary, they wanted to adhere to the previous division of labor based on standardized work instructions (2).

At times, even then, there were situations in which the workers of the whole group helped each other but these boundary crossings were temporary and the workers soon returned to their tasks as described in their job descriptions (3).

Together with the researcher and occupational health service team, in the intervention process, the workers planned a new customized work model built on the idea of partnership. The model had to be accepted by the management, and was in line with the vision presented by the management in 2003 (4).

The management of the centre, however, decided in 2004 to re-organize services into three independent production lines: catering, real estate maintenance, and cleaning (5). The pipe-line organization meant the return to a standardized mass service organization, and frustrated the team members:

"It's better if we just do our own daily work. I already knew at the beginning of the project that they wouldn't carry out the workers plan." (team member, 2003)

We called these shifts back and forth asynchronies in the change process. The depicted asynchronies were vertical (management and grass-root work), and they seemed to be the main cause of personnel problems in work-related well-being. We can, however, question whether the models developed in the intervention were in fact realistic. Were the workers' plan and the management's vision too far from the prevailing standardized mass production concept? Was there an insurmountable gap 
between goals and practice?

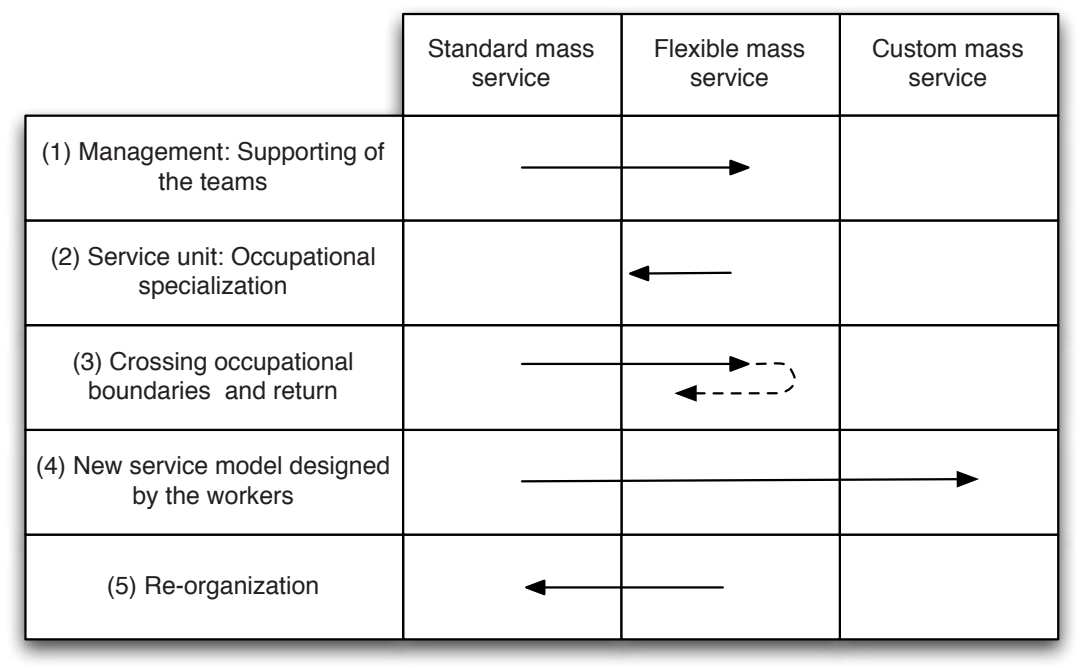

Table 3: Asynchronies in transition of service organization

\section{4.- Conclusion}

Accelerating and divergent changes in the production and service concepts pose problems to both fluent activity and work-related well-being.

When solutions are sought for work-related well-being, they are found in the transition processes of production concepts. This does not mean that we have to accept management's prevailing concepts and models, but it does mean that to be preventive, we have to analyze and conceptualize problems in work-related well-being in the context of concept transformation.

Promoting work-related well-being requires new theoretical approaches; research and analysis methods in order to be able to connect the whole organization and the disturbances perceived by the workers, rather than separate them into different (micro-macro) levels. CHAT provides good opportunities for this.

Our data and results show that changes in production and service concepts are a major challenge for research on well-being, especially since continuous change has become an inseparable part of our modern work life since the beginning of the 1990s.

In order to cope with the redesigning of production/service without undue extra health and safety problems to the employees, new types of encounters and alliances are needed between management, production designers, health and safety specialists, and local work communities. A common language is not the only aspect required for a new kind of collaboration. Novel conceptualizing, models and tools are needed to analyze and interpret transition processes and solve the ever increasing asynchronies and collapses in production and service concepts. In the rigorous transformation processes, ease of production and service processes improves both health and safety of the personnel, and productivity.

\section{REFERENCING}

Launis, K., \& Pihlaja, J. (2007). Asynchronies and disturbances as a tool in analysing well-being problems at work. @ctivités, 4(2) pp. 99-106, http://www.activites.org/v4n2/v4n2.pdf 


\section{REFERENCES}

De Greef, M., \& Van den Broek, K. (2004). Quality of the working environment and productivity. Research findings and case studies, European Agency for Safety and Health at Work.

Docherty, P., Forslin, J., Shani, A., \& Kira, M. (2002). Emerging work systems: from intensive to sustainable. In P. Docherty, J. Forslin, \& A. Shani (Eds.), Creating Sustainable Work Systems. Emerging Perspectives and Practice. London: Routledge.

Engeström, Y. (1987). Learning by Expanding. Jyväskylä: Gummerus Oy.

Engeström, Y. (1988). Reconstructing work as an object of research. The Quarterly Newsletter of the Laboratory of Comparative Human Cognition, 10 (1), 21-27.

Engeström, Y. (2000). Activity theory as a framework for analyzing and redesigning work. Ergonomics, 34 (7), 960-974.

Engeström, Y., Lompscher, J., \& Ruckriem, G. (Eds.) (2005). Putting Activity Theory to Work. Contributions from Developmental Work Research, ICHS, Volume 13. Berlin: Lehmanns Media.

European Agency for Safety and Health at Work. (2002). Research on changing world of work.

Kompier, M., Cooper, C., \& Geurts, S. (2000). A multiple case study approach to work stress prevention in Europe. European Journal of Work and Organizational Psychology, 9 (3), 371-400.

Launis, K., \& Pihlaja, J. (2005). Production concepts and learning: Changes and work-related well-being. Paper presented in RWL-conference in Sydney, December.

Mäkitalo, J. (2005). Work-related well-being in the trans-formation of nursing home work. University of Oulu, D 837. Oulu.

Pihlaja, J. (2005). Learning in and for Production. An Activity Theoretical Study of the Historical Development of Distributed Systems of Generalizing. Helsinki: University Press.

Victor, B., \& Boynton, A. (1998). Invented here. Maximizing Your Organization's Internal Growth and Profitability. Boston: Harvard Business School Press.

Virkkunen, J., Engeström, Y., Helle, M., Pihlaja, J., \& Poikela, R. (1997). The change laboratory - a tool for transforming work. In T. Alasoini, M. Kyllönen, \& A. Kasvio (Eds.), Workplace Innovations - A Way of Promoting Competitiveness, Welfare and Employment. Helsinki: National workplace development programme/Ministry of labor.

\section{RÉSUMÉ}

Il semblerait que les changements récurrents au sein des situations de travail tendent à augmenter les plaintes liées au stress, aux cadences, à la santé ainsi que le nombre des problèmes liés à la sécurité des travailleurs. Les professionnels de la santé et de la sécurité du travail cherchent à réduire ce stress et à traiter divers facteurs de risque ou divers problèmes liés à l'environnement de travail. Cependant, malgré leurs bonnes intentions, ces professionnels peuvent aussi ajouter une part de confusion avec leurs méthodes préventives et leurs recommandations faites au sein de situations marquées par la rapidité des changements qui s'y produisent. Les dynamiques de transformations des milieux professionnels ne sont pas bien comprises et appréhendées à partir d'un regard sur le travail quotidien, que ce soit du point de vue de l'organisation toute entière ou de celui de l'individu. Cet article propose d'utiliser l'approche théorique de l'activité pour conceptualiser autrement le bien-être professionnel dans les situations de changement rapide. Les concepts clés mobilisés sont les concepts qui orientent l'activité de production et de services, ainsi que de leurs asynchronismes. De multiples asynchronismes ont été observés au sein des analyses qui nous avons menées dans deux entreprises. Ces asynchronismes ont occasionné de la frustration et de la confusion, et ont diminué le niveau de motivation au travail et la perception de bien-être des employés. La nature de la charge correspondante a été dénommée la 
« charge de perturbation». Les données et les résultats que nous avons obtenus montrent que les changements rapides des concepts sous-jacents aux activités de production et de services constituent un enjeu majeur pour la recherche sur le bien-être, notamment puisque les changements continuels au cours d'une carrière professionnelle sont désormais devenus incontournables depuis ces dix dernières années.

\section{MOTS CLÉS}

Théorie de l'activité, concept de production, bien-être professionnel, asynchronisme

\section{RESUMEN}

Los cambios constantes en los lugares de trabajo parecen incrementar el apuro, el estrés, las quejas sobre la salud y los problemas de seguridad de los trabajadores. Los profesionales de la salud y de la seguridad laboral intentan reducir el estrés o remediar diferentes problemas de medio ambiente y factores de riesgo en el trabajo. Sin embargo, a pesar de sus buenas intenciones, en situaciones de cambios rápidos, estos profesionales pueden generar confusión con sus métodos y recomendaciones habituales. No comprenden bien la dinámica de las transformaciones del puesto de trabajo desde la perspectiva del trabajo diario tanto de la organización como de los individuos. En este artículo, utilizamos el enfoque teórico de la actividad para reconceptualizar el bienestar atribuible al trabajo en situaciones de cambios rápidos. Los conceptos clave son los de producción y servicio, así como el de sus asincronías. Se observaron varias asincronías en el análisis de los dos casos en diferentes tipos de organizaciones. Estas asincronías causaron frustración, confusión y disminuyeron la motivación laboral y la sensación de bienestar de los empleados. El tipo de carga se dio a llamar carga de perturbación. Nuestros datos y resultados muestran que los cambios rápidos en los conceptos de producción y de servicio son un desafío importante para la investigación sobre el bienestar, especialmente desde que los cambios continuos se han transformado en una parte inseparable de la vida laboral desde los últimos diez años.

\section{Palabras Claves}

Teoría de la actividad, concepto de producción, bienestar asociado al trabajo, asincronía 